\title{
2. The unfinished business of nation-building
}

\author{
John Butcher
}

\begin{abstract}
The rhetoric, mythology and practical consequences of nation-building are inextricably bound in the Australian story. Iconic infrastructure projects such as the Snowy Mountains Hydro-Electric Scheme are embedded in the collective national memory because of their audacity, scale and impact upon the shaping of the nation. However, it can be argued that other national institutions, from the ABC, to the CSIRO to the Australian Parliament also had nation-building as a primary raison d'etre. In a decidedly post-Keynesian age, however, the ascendancy of economic rationalism as the dominant public policy framework appeared to have consigned nation-building to an historical footnote. It has for some time been out of fashion to expect governments to intervene to correct market failure, other than through the reduction of regulatory or policy barriers to market participation. The nation was largely 'finished': the market largely 'mature' and the private sector could be leveraged to fill any gaps in the national patchwork using a mixture of deregulation and public private partnerships. This chapter asks the following questions: Has nation-building really been abandoned as a policy frame, or has it simply gone underground? Are today's major infrastructure projects the natural descendents of Keynesian era nation-building? What are the new frontiers of nation-building in the information age?
\end{abstract}

\section{Why 'Nation-Building'?}

In the months leading to the 2007 Australian general election, 'nation-building' re-entered the national political debate in spectacular fashion. The major political parties vied with one another to prove their nation-building credentials. The then Opposition Leader, Kevin Rudd, former Opposition Leader, Kim Beasley, then Prime Minister John Howard and then Deputy Prime Minister and Leader of the National Party, Mark Vaile - among others - invoked the term at various times during the federal election campaign. Even State Premiers like the former Premier of Queensland, Peter Beattie, weighed in on the nation-building angle. In so doing, each evoked a paradigm of nation-building as a policy framework for meeting the long term social and economic obligations of government.

The election campaign embedded the term in the consciousness of politicians, the electorate and the media. 'Industry welcomes nation-building Budget', or 
so-said the headline for Tony Jones' May 2008 Budget night interview with Australian Industry Group Chief, Heather Ridout on ABC TV's flagship program The 7:30 Report. ${ }^{l}$ Was this merely a rhetorical 'hook' for a newspaper storyline or a media 'grab' or did it signal a genuine shift in the policy focus of governments? For his part, the then Opposition Shadow Treasurer, Wayne Swan (now Treasurer), declared that the Howard Government's Budget 'fails the future test'. This, of course, begs the question about what 'tests' might reasonably be applied to putative nation-building initiatives. ${ }^{2}$

\section{A contested term}

In Australia the term 'nation-building' is most often associated with the heroic efforts of Colonial and Australian visionaries who recognised that the potential of the continent could be unleashed only through the direct financial and policy intervention of government. However, the term also carries different meanings and emphases in different contexts. For example, nation-building can refer to the re-building or establishment of the institutions of civil society in 'failed states' or even the reconstructing nations in the wake of 'regime change'.

In this context, it might be said that, in a sense, Australia has in recent years shifted its nation-building efforts 'off-shore' to developing countries within its sphere of influence, such as the Solomon Islands or Papua New Guinea, where it is engaged in restoring or establishing civil society institutions, or as part of its commitments to post-war/post regime-change reconstruction in East Timor, Afghanistan and Iraq.

Social historians might approach the subject of nation-building as a form of national or cultural narrative in which the nation - or, more pertinently, the national identity - is the cumulative product of social, political and economic relations, relations between settlers and indigenous peoples, changing gender roles, the emergence of social movements or the experience of war.

Although each of these offers a legitimate and valuable lens onto our national identity, it is generally accepted in the Australian context that 'nation-building' refers to a deliberate policy framework whose aim is to construct the social and economic infrastructure of the nation state. For the purposes of this chapter, nation-building will be addressed as a policy frame which is, in part, an extrapolation of a 'settler narrative'.

\section{Nation-building and the settler narrative}

Nation-building in 'new world' nation-states of Australia, New Zealand, Canada and the USA, is a 'settler' narrative. It is a narrative concerned with taming the landscape, carving a country from the wilderness, conquering the 'tyranny of distance' and harnessing the land's bounty for productive purpose. 
In some ways the Australian narrative differs from that of other settler societies. For example, whereas Australia's nation-building story is concerned with the struggle against a hostile landscape, physical isolation and remoteness from the 'mother country', the story in Canada is, in essence, about the geopolitical imperative of establishing a nation in a race against a powerful, ambitious and expansionist neighbour, the United States. The settler narrative of the United States, by contrast, is imbued with the notion of manifest destiny - the right, sanctioned by Divine Providence, to claim the continent for republican democracy.

Often, the nation-building story is a 'retrospective narrative': a lens for interpreting the past rather than a framework for charting a prospective future. As a retrospective narrative, there is, of course, a tendency to enlarge, embellish and emboss past events and even imbue them with almost mythic status.

\section{An Australian story}

In Australia, the nation-building story has traditionally centred on 'iconic' infrastructure projects. This is the imagery most often invoked by politicians when trying to tap into a transcendent national story. Commonly cited examples include the Snowy Mountains hydroelectric scheme (the 'Snowy') or even the Sydney Harbour Bridge. ${ }^{3}$ Thus, the story of Australia is that of a fledgling nation fighting above its weight. It is also, in part, a story about 'visionary' projects whose scale, audacity and symbolism transcended mere function.

Past investment by government in strategic national infrastructure was a response to perceived market failure - the incapacity of markets then prevailing to deliver public goods. Governments felt they had to step in because only government could command the resources to deliver nationally strategic projects.

Despite the importance of nation-building in the national historical narrative, however, Michael Pusey argued in his 1992 book, Economic Rationalism in Canberra: A Nation-Building State Changes its Mind, ${ }^{4}$ that the contemporary Australian state had largely turned its back on the federation era visionaries and post war Keynesian re-constructionists in favour of an instrumentalist economic rationalism in which the market is king, government is small, and government's role in constructing the nation is largely finished.

Should we accept that the nation is 'finished' and, if not, what does 'nation-building' mean today? Importantly, what do politicians and the public generally understand by it? Is nation-building — like 'mateship' or the 'fair go' - just a symbolic feel-good catchphrase (whose meaning is, nevertheless, vigorously contested) or does it describe a genuine policy frontier with a broadly agreed framework and preferred policy instruments? 


\section{More than bricks and mortar}

Although the popular consciousness in Australia links nation-building with physical infrastructure: with roads, railways, ${ }^{5}$ reservoirs and dams, in reality nation-building is about more that just bricks and mortar. Frequently overlooked is the contribution to nation-building of core civic, cultural or social institutions. It can be argued that nation-building was a driving force in the establishment of institutions such as the Post Master General (now Australia Post), the Australian Broadcasting Corporation (the $\mathrm{ABC}$ ) or the Commonwealth Scientific and Industrial Research Organisation (the CSIRO) - or, for that matter, the Commonwealth Bank or Telecom (now Telstra) which, unlike their privatised descendants, were not initially concerned solely with maximising financial returns to their shareholders. Even Australia's Parliament, our body of law and our democratic system of government, are essential components of ongoing nation-building.

It can also be said that past investment in public health, education and the arts had the broader purpose of creating a particular kind of society embodying those values held by broad consensus to be quintessentially 'Australian'. If we accept that proposition, what then can we say about the contemporary attitude towards these institutions? Does privatisation or disinvestment in public health and education, for example, signal a diminishing attachment to these values?

Certainly, a number of commentators on contemporary Australian affairs (Pusey 1992, 2003; Mackay 1993, 2007; and Aitkin 2005) have expressed concern that the diffusion to Australia of neo-conservative precepts of government (see Mishra 1990:69-95; Gould 1993: 129-130; Glennerster 1989:108-128) have threatened to seriously undermine public confidence in the capacity of public institutions to address societal needs.

It is possible that future nation-building enterprises will have 'soft ' and 'hard' elements. Examples of soft nation-building might include such things as reconciliation between indigenous and non-indigenous Australia or achieving an Australian republic. Hard nation-building — as ever — will focus on delivering physical infrastructure to support the nation's productive capacities. In all likelihood, nation-building enterprises deserving of the name will embody soft and hard elements - structural reforms to health or education, for example, will require major investments in social, human and physical capital.

\section{A nation-building doldrums}

During the 1980s and 1990s it became almost an article of faith for Australian governments - Commonwealth and State, Labor or Coalition - that governments needed to refocus and align their efforts with their 'core business'. Nation-building, it seemed, was not core business, at least not in the traditional sense of iconic infrastructure projects or the creation of new institutions. Policy 
mixes emphasising deregulation, commercialisation, corporatisation, downsizing and privatisation suggested that, as far as Australian governments were concerned, the time for active nation-building has passed.

Even so, the Hawke and Keating Labor governments made policy forays that might, retrospectively, be seen as broadly nation-building in their intent. For example, the Hawke Labor government's monetary and fiscal reforms of the early 1980s could be characterised as having established a new frontier for nation-building in which policy instruments and structural reforms take the place of bricks and mortar. These were durable reforms that transformed the national economy and provided the bedrock for Australia's strong economic performance to the present day.

In 1991, the Hawke Labor Government allocated \$816 million over five years to the Building Better Cities Program under which the Commonwealth, State and Territory Governments would work co-operatively to improve urban development processes and the quality of urban life through improvements to urban planning, service delivery and co-ordination within and between the various levels of government. By the mid 1990s the Keating Labor government was making largely symbolic nation-building gestures in the form of grand policy statements, such as One Nation, Working Nation or Creative Nation. Although these employed the rhetoric of nation-building, they mainly amounted to a 're-branding' of existing programs without significant new investment.

Although these latter efforts might be legitimately cast as attempts to weave or strengthen the fabric of contemporary Australia, it might be said that they failed somehow to capture the public's imagination - possibly because they lacked the audacity and vision of past efforts. Apart from the significant structural reforms of the Hawke era, these initiatives did not survive the election of the Howard Coalition government in 1996. Not only had they failed to achieve the political or institutional momentum that would see them continue under a new administration, they had become inextricably associated with the Australian Labor Party's 'brand' and so, could be jettisoned without a backwards look by the incoming Howard administration.

\section{From back burner to front burner}

Politicians, academics and commentators are once again talking about the need for governments to intervene in significant ways to provide for the security of our water supply or to provide sustainable, clean energy. Achieving these goals is increasingly regarded by large parts of the electorate as essential for our national survival. Furthermore, it can be argued that such goals are, at present, far beyond the capability and capacity of the market to achieve on its own.

John Howard, in a 2001 address to the Centenary Conference of the Institute of Public Administration, acknowledged a nation-building past when he lauded: 
[t] he great national issues of the past century - the turning of the dream of Federation into reality, post war reconstruction and repatriation, the peaceful settlement of millions of migrants, the vast nation-building projects like the Snowy and our rail and road networks to name just a few... 6

As the leader of a government with, at the time, avowed 'small government' credentials, the Prime Minister's remarks fell short of acknowledging a nation-building future. The nation, now 'built', needed only ongoing maintenance.

By 2005, however, the Howard government appeared to have re-discovered nation-building as a policy framework. For instance, John Howard, in an interview on Channel Seven's Sunrise program, portrayed the Darwin to Alice Springs railway as an exercise in contemporary nation-building. ${ }^{7}$ Built as a public private partnership with $\$ 1.3$ billion in financial assistance from the Commonwealth, Northern Territory and South Australian governments, the line is the fruition of a promise first made by the Commonwealth in $1911 .^{8}$ The press, however, characterised the Commonwealth's \$191 million contribution to the railway (opened by the Prime Minister in January 2004) as an attempt to shore up beleaguered conservative governments in the Territory and South Australia: nation-building lite, perhaps. ${ }^{9}$

Despite misgivings about the economic rationale for the Alice to Darwin link, it has proved popular with the public - it has even been dubbed 'the Steel Snowy' in an evocation of the nation-building spirit. ${ }^{10}$ Indeed, a strong residual public affection for some of Australia's more iconic nation-building projects was demonstrated when in 2006 a public outcry over plans by the Commonwealth to divest itself of the government's remaining shares in Snowy Hydro resulted in the Commonwealth reversing its decision. ${ }^{11}$ This reversal, according to the Prime Minister, reflected a recognition of the 'overwhelming feeling in the community that the Snowy is an icon. It's part of the great saga of post-World War II development in Australia.' 12

In part, the Snowy Hydro story suggests a degree of 'privatisation fatigue' in the community and a degree of public unease about the transfer of public assets into private hands under the pretext of improving efficiency and promoting 'choice'. It may also signal a revival of a belief in the potential of government to use its legislative and financial muscle to meet the challenge of national survival.

Both the Alice to Darwin Railway and the reversal of the Snowy Hydro privatisation demonstrate that nation-building is inextricably linked to the political currents of the day. For that matter, recourse to the rhetoric and 
symbolism of nation-building is a natural and useful response in the face of internal and exogenous political threats.

\section{The Rudd ascendancy}

The rhetoric - if not the substance - of 'nation-building' is beginning to define the boundaries of contemporary national political debate. In January 2007, then Prime Minister, John Howard, seemed to allude to something approaching a nation-building agenda when he spoke in the following terms to the National Press Club about his plan to secure Australia's 'water future':

By getting the big things right - by reforming and retooling our economy - we can afford to do the bold things - like saving the Murray-Darling Basin from economic and environmental decline, like securing our nation in a time of threat and uncertainty, like positioning Australia as a twenty-first century energy superpower, like meeting the challenge of climate change in a way that supports our competitiveness and plays to Australia's strengths. Water scarcity is a major national challenge. And there will be other challenges we must confront in the years to come. But with the resilience, adaptability and boldness Australians have shown in the past, they can be overcome. ${ }^{13}$

For his part, then Opposition Leader, Kevin Rudd, remarked when he spoke to the Australia Industry Group in February 2007:

Building the infrastructure for a modern, dynamic economy is a major priority for Labor ... Rather than leave it entirely to the States or to the private sector, I want to see the Australian government return to its true nation-building role by investing in the nation's infrastructure. ${ }^{14}$

Kevin Rudd's announcement on 21 March 2007 that, if elected, Labor would roll out a $\$ 4.7$ billion national high-speed broadband network, effectively threw down the nation-building gauntlet. In his 10 May Budget Reply Speech, Rudd made the following comparison:

In the nineteenth century, governments laid out railway networks as the arteries of the economy. In the twenty-first century, governments around the world are ensuring that high speed broadband networks are laid out — as the arteries of the new economy ... This is the nation-building that the nation needs. ${ }^{15}$

Of course, these announcements are consistent with long-standing ALP policy to pursue nation-building. Indeed, Chapter 6 of the Australian Labor Party's National Platform and Constitution 2007 is dedicated to the question of nation-building. ${ }^{16}$ Since taking office, the Rudd Labor Government has established a Ministry of Infrastructure, Transport and Regional Development together with a new statutory advisory council, Infrastructure Australia, to: 
... provide advice to Australian governments about infrastructure gaps and bottlenecks that hinder economic growth and prosperity. It will also identify investment priorities and policy and regulatory reforms that will be necessary to enable timely and coordinated delivery of national infrastructure investment. ${ }^{17}$

Infrastructure Australia is portrayed as a 'key driver in the Rudd Government's plan to fight inflation'. This it will do, according to the government, 'by boosting the economy's productive capacity [and] unlocking infrastructure bottlenecks like clogged ports and congested roads'. The government has also pledged to 'develop a strategic blueprint for Australia's infrastructure needs and ensure future projects are determined by economic, social, and environmental needs — not short-term political interests' ${ }^{18}$

\section{Nation-building - a revival?}

Until recently, nation-building has seldom featured in the utterances of politicians or public commentators except when extolling (or lamenting) the halcyon days of grand public infrastructure schemes of such a scale that they could only be underwritten by government: schemes designed to harness the potential of our natural bounty and, in so doing, create a new society. Indeed, one might have been justified in concluding that nation-building had been consigned to the status of an historical footnote.

Every now and then, when someone promotes a grand - and sometimes silly - scheme to reverse the nation's rivers, water its deserts or in some way profoundly transform its productive heartland, Australians sit up and take notice. Somehow nation-building is inextricably bound up with the 'idea' of Australia and still resonates in the popular consciousness. With the froth and bubble of a long election campaign now behind us it is prudent to ask whether nation-building is set to 're-surface' as a contemporary policy and political discourse.

Nation-building appears set to undergo a renaissance as the Australian national 'idea' is re-forged in the cauldron of drought and climate change. The 2008 federal election demonstrated a clear recognition on the part of policy-makers and the electorate that the emerging challenges of climate change and water security will require concerted government action and that 'the market' has neither the capability or capacity to meet these challenges without the backing and muscle of governments.

The content and direction of nation-building may also be shaped by other factors such as the resources boom, an unprecedented budgetary surplus, the new Federal government's resolve to address key capacity bottlenecks and, perhaps not least, public weariness with the excesses of new public management. 
Globalisation too may define a new policy frontier for nation-building — both as a consequence of the economic stimulus it provides as well as the threats it poses to national identity and national institutions. In this light, policies mandating the transition from analogue to digital communications, or policies opening up of the telecommunications market (through — ironically — the corporatisation of Telecom and the subsequent sale of its successor, Telstra) might be seen as exemplars of late twentieth century nation-building.

This will not be comfortable territory for politicians, institutions and a public obsessed with tax cuts, interest rates and budget surpluses, not to mention a horror of public borrowing. The battlelines drawn around Labor's ambitious plans for national broadband illustrate the tension between values of fiscal rectitude and visionary risk-taking. It has ever been thus in the business of nation-building.

Confronting these and other challenges may stir governments and the electorate from the 'comfortable and relaxed' complacency into which the nation seems to have lapsed. We may yet realise that the nation is not 'finished' by a long shot and governments will re-discover a mandate for big, bold initiatives.

\section{References}

Aitkin, Don. 2005. What was it all for? The re-shaping of Australia. Allen \& Unwin.

Glennerster, Howard. 1989. 'Swimming against the tide: the prospects for social policy'. Chapter 5 in Martin Bulmer, Jane Lewis and David Piachaud (eds) The Goals of Social Policy. Unwin Hyman. pp 108-128.

Gould, Arthur. 1993. Capitalist Welfare Systems: A comparison of Japan, Britain and Sweden. Longman.

Mackay, Hugh. 1993. Reinventing Australia: The Mind and the Mood of Australia in the 90s. Angus \& Robertson.

Mackay, Hugh. 2007. Advance Australia Where? Hachette Australia.

Mishra, Ramesh. 1990. The Welfare State in Capitalist Society. Harvester Wheatsheaf.

Pusey, Michael. 2003. The Experience of Middle Australia: The Dark Side of Economic Reform. Cambridge University Press.

\section{ENDNOTES}

1 Australian Broadcasting Corporation, The 7:30 Report, Broadcast: 08/05/2007, accessed at http://www.abc.net.au/7.30/content/2007/s1917924.htm

2 Australian Broadcasting Corporation, The 7:30 Report, Broadcast: 08/05/2007, accessed at http://www.abc.net.au/7.30/content/2007/s1917892.htm

3 Although calling the latter an exercise in nation-building rather stretches the notion, it does serve to demonstrate the propensity to selectively re-interpret our nation-building past. 
4 Michael Pusey, Economic Rationalism in Canberra: A Nation-Building State Changes its Mind, Cambridge University Press, 1992.

5 Of course, the history of failed attempts to create a national standard gauge railway system in the first part of the twentieth century offers a salutary lesson in the perils of nation-building within a federal system of government.

6 The Australian Public Service, speech given by the Prime Minister, John Howard, to the Centenary Conference of the Institute of Public Administration, 19 June, 2001, accessed at http://australianpolitics.com/executive/publicservice/01-06-19howard.shtml

7 John Riley interview with John Howard on Sunday Sunrise, 6 March 2005, accessed at http://seven.com.au/sundaysunrise/politics/19343

8 Alice Springs-Darwin Railway, accessed at http://www.infrastructure.gov.au/transport/ programs/rail/alice.aspx

9 Mary Gearin, Alice to Darwin railway go ahead surprises many, Landline, First Published 3/12/2000, accessed at http://www.abc.net.au/landline/stories/s217515.htm

10 See Northern Land Council, Doing Business on Aboriginal Land, at http://www.nlc.org.au/html/busi_infra_case_1.html

11 Lateline, Australian Broadcasting Corporation, TV Program Transcript, Broadcast: 02/06/2006, accessed at http://www.abc.net.au/lateline/content/2006/s1654370.htm

12 The Snowy Mountains Scheme, accessed at http://www.cultureandrecreation.gov.au/ articles/snowyscheme/

13 'John Howard outlines visionary \$10 billion programme to secure Australia's water future',

Thursday, 25 January 2007, accessed at http://www.malcolmturnbull.com.au/Pages/Article.aspx?ID=642 14 'Prosperity Beyond the Mining Boom', Speech to The Australian Industry Group, Canberra, 27 February 2007, accessed at http://pdf.aigroup.asn.au/representation/ events_and_speeches/Kevin_Rudd_Speech_270207.pdf

15 Federal Opposition Leader, Kevin Rudd, 'Budget Reply speech to the House of Representatives', 10 May 2007, accessed at http://australianpolitics.com/2007/05/10/ 2007-budget-reply-speech-kevin-rudd.shtml

16 ALP National Platform and Constitution 2007, Chapter 6: Nation Building, pp 72-99, accessed at http://www.alp.org.au/download/now/2007_platform_chapter6.pdf

17 http://www.infrastructure.gov.au/department/infrastructureaustralia/index.aspx

18 Rudd Government to Dramatically Overhaul National Infrastructure Policy, Joint Media Statement, 21 January 2008 AA004/2008 Joint, accessed at http://www.minister.infrastructure.gov.au/ aa/releases/2008/January/AA004_2008.htm 